\title{
Solon Karthak and Travelogues in Nepali Literature
}

\author{
Norden Michael Lepcha \\ Former Assistant Professor of English, Visva-Bharati University, Santiniketan \\ Email: nordenmike@gmail.com
}

\begin{abstract}
Apart from Nepal and Bhutan, Nepali is the dominant language of the lower Himalayan and sub-Himalayan regions of India. Since the beginning of the twentieth century, many important literary organizations from this region have been publishing books and journals in Nepali. In 1992, Nepali was recognised as the $19^{\text {th }}$ official Indian language and included in the Eighth Schedule of the Constitution of India. It has been recognised as one of the modern languages of India by the Sahitya Akademi, or Academy of Letters, of the Indian government since 1975; and the prestigious Sahitya Akademi Award has been bestowed on the best literary works of Indian Nepali writers along with other Indian languages every year. The 2019 award was given to Solon Karthak for his anthology of travel narratives Visva Eauta Pallo Gaon (2013). As an Indian national residing in Kalimpong, West Bengal, Karthak has been writing for a long time but since he writes in Nepali, many in India have no clue about him probably because of the language barrier. Indian Nepali literature is not often translated into English, and remains inaccessible to most people within India and outside it. Solon's thirst to travel and passion for literature shaped him into an excellent travel writer, in fact one of the forerunners in this genre in Nepali literature. This article will give an overview of Solon Karthak's travel writings which are not only descriptive but have an artistic touch in them. His contribution to develop and bring Niyatra (Subjective Travelogue) into mainstream Nepali literature shall always be remembered.
\end{abstract}

Keywords: travelogues, Nepali, Salon Karthak, Sahitya Akademi Award

Solon Karthak was born on $24^{\text {th }}$ March 1946 at Rimbick, Darjeeling but spent most of his life in Kalimpong where he is now settled with his family at Bong Busty. He was the eldest son of Late Aching Karthak Lepcha and Late P L Karthak. He did his early schooling from Scottish Missionaries' University Institution, Kalimpong and got his Degree in Arts from Kalimpong College. He did his Masters in Nepali Literature from North Bengal University and Masters in Education from North Eastern Hills University, Shillong. He is now one of the established Indian writers in Nepali language. He started writing since 1970s. He has already been honored with Shrastha Puraskar (1992), Lal Maan Sancharani Puraskar (2016), Dr. Sobha Kanti Thegin Puraskar (2017), all three awards from Sikkim and Parasmani Pradhan Smriti Puraskar (2011) awarded by Sahitya Adhayan Samiti, Kalimpong, DGHC. Recently he has received the Sahitya Akademi Award 2019 for his travelogue Visva Eauta Pallo Gaon (The world is just a next village) which was published in 2013. This has also brought him a lot of attention from a pan-Indian readership and from Nepali people residing in different parts of the world. Karthak used to work as a Mission Executive in an international organization in Kathmandu. He has retired and at present is leading a life as a full-time writer.

In a foreword written in Visva Eauta Pallo Gaon (2013), Solon's school friend Mohan Thakuri mentioned: "In spite of being born and brought up in one of the most remote parts of

(C) AesthetixMS 2020. This Open Access article is published under a Creative Commons Attribution Non-Commercial 4.o International License (http://creativecommons.org/licenses/by-nc/4.o/), which permits non-commercial re-use, distribution, and reproduction in any medium, provided the original work is properly cited. For citation use the DOI. For commercial re-use, please contact editor@rupkatha.com. 
India, Solon always yearned to travel and experience the unknown." (p. 8). As a child Solon Karthak was heavily influenced and inspired to travel after coming across Jules Verne's Around the World in Eighty Days which was in his school's curriculum. In his later life he was influenced by Khushwant Singh's writings that featured in The Illustrated Weekly of India and Beliat Tira Baralingda, a travelogue by a Nepali writer from Nepal, Dr. Taranath Sharma. Other Nepali writers who influenced him were Lal Singh Bangdel, Raj Narayan Pradhan, Indra Bahadur Rai and M. N. Gurung. This thirst to travel and passion for literature shaped him into an excellent travel writer, in fact one of the forerunners in this genre in Nepali literature. The five travelogues published till date, namely Samudra wari Samudra pari(1986), Videsh Tira Ringdai Ghandaa(1991), Padyatra Gaon ko Phanko Videshko(200o), Visva Eauta Pallo Gaon (2013) and Golard Ghumai ka Raang Haru (2018) comprise of individual essays and articles that he wrote about different places and people over a long period of time and have undisputedly established Solon's identity as travel writer in the Indian Nepali literary circle. His travelogues are not merely records of simple facts about the places he visits. His travel accounts on the contrary are interesting, as they are creatively presented subjective essays and stories of his experiences through which he takes his readers to different places, people and moments.

Travel writing as a literary genre was recognized by Nepali literature very late, even though many believe that travel writing in Nepali language started with King Gananiraj's travels in 1893. In spite of this, travel writing in Nepali literature progressed very little in all these years. Travel writing in Nepali language from Indian Nepali writers started even later, only in 1957 with Laingsingh Bangdel's Europe ko Chitti (Letter from Europe). Thereafter he published another travelogue Spain Ko Samjhana(1963) (Memories of Spain). However these were just few essays.

It is quite interesting that Nepali literature categorically separates objective travel writing from a subjective one. According to Professor Bal Krishna Pokhrel, a travelogue written just to present facts and figures about a place the writer visits is known as "Yatra Lekh" or a "Travel Account' but a travelogue creatively presented with personal experiences, thoughts and views is known as "Niyatra". So the basic difference between Yatra Lekh and Niyatra is the presentation of the subject. Niyatra seeks to present places and people in a more subjective and creative manner. It does not simply account facts, but the writer often weaves a beautiful story of his experiences of the places he visits, and of the people he meets. However one has to keep in mind that the places, people and experiences in Niyatra are not fictitious. They are real, of flesh and blood, whom the writer meets at different points of his travel. It is through these stories the writer describes about his travels and each time reveals to the readers the mysteries of the places he visits. Many are of the opinion that Solon Karthak's importance lies in developing and bringing in Niyatra into main stream Nepali literature even though this form of subjective travelogue in Nepali literature starts with Dr. Taranath Sharma's Belayat Tira Baralingda. Dr. Taranath considered subjective travelogue as the highest form of experience accounting.

After a long hiatus of travel writing in the Nepali language, Solon Karthak published his first anthology of travel experiences called Samudra wari Samudra pari (1986). This is an anthology where he collaborates with his friends Rajendra Rongong, Gyanendra Rongong, and John Dick Khawas. In the introductory lines of this anthology, he writes that the endeavour is to present information about the world through creatively written stories and further goes on to claim that the work he is doing is important. Towards the end of his introduction he ambitiously says that "this is just the beginning." Without dispute the remark was made, and it proved true with the four Niyatris or subjective travelogues that followed. When asked by this writer what prompted him to become a travel writer, Karthak stated: 
As there was hardly anyone writing travelogues I felt that this genre would be interesting. I thought that I could document my travels but I wanted to present it colourfully. I also wanted to contribute something new and original to Nepali literature. I am hopeful that travelogues will make big in days to come. (Lepcha, 4 May, 2020)

In his travel writings Solon Karthak takes his readers to different places all over the world. He also writes about renowned places and cities of India like Delhi, Rajasthan, Orissa, Goa, Mumbai, Kanyakumari, Andaman Nicobar Islands and Sikkim. This is not the end, as at times the little rivulet or the mountains on the other side of his home or some nondescript village yet to be explored by a traveller becomes the subject of his travelogue. In an interview given to the unnamed Darjeeling correspondent of The Sikkim Express (Mr. Reza Pradhan) on the $25^{\text {th }}$ of January, 2020 after receiving the news that he has been awarded the prestigious Sahitya Akademi award for 2019, Karthak stated:

I am happy that my name was chosen for the Sahitya Akademi award to be presented in Delhi on February 25. It took me some time to get it but I am proud....The travelogues that I have written are mostly of travel to various places in the country and abroad. I have visited about 35 countries and written about the places I have been to like USA, Canada, New Zealand, Africa, France, Netherlands, Italy and in our country like Kanyakumari, Madras, Arunachal Pradesh among others. I had visited these places on work or through my personal interest.

When asked by this writer how he felt after receiving the Sahitya Akademi 2019 award, and whether he expected to receive it at all, Karthak instantly replied:

I felt happy, not only for myself but also for my family who always supported me and for my readers who enjoyed and believed in my writings. The recognition is not limited to my writing but for our community at large. It is because of them I get inspired to write.

No. It came as a shock especially when I came to know that I had received it for a book that had been published in 2013. Because after that I had published another book Golard Ghumai ko Raang Haru in 2018 and at present I am working on another one." (Lepcha, 4 May, 2020)

In his writings Solon Karthak gives detailed information about the historical, geographical, cultural, socio-economical facts of the places. Personal experience becomes an integral part of his travelogues. It is through the narratives of these experiences he takes his readers for a journey to learn about places, people and things. The experiences do not simply shed light to the scenic aspect of the place but also seeks to tell a lot about the culture, livelihood and psychology of the people living there. Solon is a passionate traveller. He feels elated when he visits places and writes about its experiences. These experiences in turn shed light to the scenic beauty of the place, the psychology of the people living there, the culture, the history, the socio economic aspect, the life, the virtues and the vices of the place.

"Dinosaurs Ghumney Dara Haru Dulidinda" (Loitering in the Hills Where Dinosaurs Roam) accounts Salon's visit to the American Christian land of Colorado Springs. He is mesmerized by its rich history. The all-round development of the place from a small gold mining town to a tourist hub with ample opportunities makes it a dream mountain. He wants to experience the peak and accompanies his doctor friend. In the essay, America is portrayed as a clean country not just because of its appearance but also because of the mentality of the people living there. In "Paris ko Prayar Notre dame ra Eiffel Tower" (Synonyms of Paris- Notre-dame and Eiffel Tower ) the monumental tower fills him with awe and in the process of describing it he even 
mentions the names of people involved in its construction. He visits Thomas Hardy's house in "Khar ko Chana Haley ko Hardy's Cottage"(Hardy's Cottage with a roof of hay) and describes the cottage in detail. His friend Mrs Lizzy, who is an English Literature student, guides him through and gives him much information about the writer's life. As a writer Solon feels proud to have visited Hardy's house, it is an experience he cherished. The train journey that he takes in Italy and other European countries fills the readers with awe and make them wonder at the technological advancement of these places.

But it is not just the high technology of the Euro train that Solon writes about. In his essay "Sicily Dekhi Zurich Samma ko Eurotrain Yatra" (Euro train journey from Sicily to Zurich) he describes his co-travellers. He finds the travellers so engrossed with their books, laptops and pets that the person sitting next to them becomes insignificant. He feels lonely. In "Bhramit Drishya ra Dirghayu Sarak Sangha Sakshatar" (Encounter with Awe Inspiring Sight and a Long Lasting Road) Switzerland, along with its incomparable beauty, teaches Solon two important lessons through his personal experience. At a zebra crossing the traffic light suddenly turns green for the vehicles. An old man had already stepped onto the road. The driver delays and motions the old man to cross the road. In response the old man steps backs to the footpath and turns down the driver's offer and prefers to heed the traffic rules instead. In another incident a Swiss engineer friend takes Solon to his work site where he is working on the construction of a new road. He casually asks his friend how long will the road last. His friend says 'forty years at least.' Solon ends the essay with an account of the road back home constructed forty hours ago, heavily damaged after incessant rains.

His "Italy ko Pahilo Bhojan" (First Meal in Italy) accounts about the food that is served after a long and tiresome journey to Italy. He was expecting that rice would be served like it is done at home. When food finally comes in the form of bread, boiled vegetables and green salad, he realizes that their food habits are different from his. His "Surya ko Pahilo Kiran Chumney Bhumi" (Land Kissed by the First Rays of Sun) describes huge cattle farms in New Zealand where thousands of sheep and goats are reared. He gives an idea about the lifestyle of these farmers. In the same essay he also speaks about how in New Zealand, the local Maori people had lost their lands and hope to the European colonisers. Similarly, in another essay he writes about the hospitality of the Korean people where they offer fruits to welcome guests at home and people from Singapore who offer lift and reach travellers to their respective destinations, and at the same time educate the readers about their culture and national policies.

Not all the places Salon visits are beautiful nor are all his experiences wonderful. Nonetheless in all his essays he seeks to ponder upon various issues related to the places he visits. The rampant corruption and ill treatment of migrant workers in Malaysia and many of the Asian countries show the darker side of society. In "Burmese Gorkhali Dighbir" (Dighbir the Gorkha from Myanmar) Solon meets many people of Nepalese origin who have been cheated as well as exploited by various foreign employment agencies in Malaysia. As a result of this corrupt system many of them find their dreams of earning and leading a decent life shattered. In "Ghora ko Masu Octopus ko Bhutwa ra Eawta Nursing Home" (Horse Meat, Fried Octopus and A Nursing Home) he visits a Nursing Home (an old age home) in Italy. He tries to give the readers an idea about what it is to live in an old age home. Through the character sketch of various old people at the Nursing Home, Solon seeks to describe the pathetic lonely condition of old people in Europe. He feels that the very concept of an old age home is a vice and a curse in a modern society. According to him, the Western world which claims to be advanced and learned is in reality just living in 
materialistic comforts. They are psychologically hollow, lonely, and pathetic, without any peace and hope.

In "London ko Dharaha ra Gorkha Musuem ko Parikrama" (Tour of the Tower of London and Gorkha Museum) Solon gets a chance to visit the Tower of London and Winchester's Gorkha Museum. According to him the museum is not only a living testimony about the bravery of the Gorkhas, but it also underlines the fact that their achievements make them only brave, not intelligent. In "Maynmari Haru Thana ko Jhai Komal Chan" (The Kind Hearted Burmese People) he shares a comical experience at a restaurant at Yangon, Myanmar where he goes with a Nepali friend Imnath. They could not speak and understand Burmese. On the other end, the waiter understood only Burmese. They place order for their food after much problem caused by the language barrier. Finally when their food comes they find a fish weighing approximately a kilogram each served with rice. They finish their dinner with much effort and that night they pay 8000 Chyat (Burmese currency) for the food which is equivalent to a nurse's one month's salary in Burma. “Aashu ko Thopla ghai Desh Sri Lanka” (Sri Lanka, A Country Resembling a Tear Drop) describes Sri Lanka's scenic beauty. Solon finds many places there similar to the pine forests of his native land. The beauty is however over shadowed by reminiscing about the bloody movement of the Tamil Tigers. In "Traffic Light Nabhaye ko Rajdhani Thimpu" (Thimpu, the Capital City with no Traffic Lights) the carbon negative policies of the Bhutan government show their consciousness on environmental issues. The rich cultural legacy of the place is time and again highlighted in the narrative. However Solon feels that the historical fact about the forceful displacement of thousands of Nepali people from Bhutan in late 1980s and early 1990s is a black blot in this kingdom's history. The cruel act can never be pardoned. He also points out that the rich cultural heritage so far safeguarded by the Bhutanese people is slowly eroding. With Hollywood influences, Domas are becoming Britneys and Lakhpas are becoming Leonardos.

At times in his essays Solon alludes to his native country and hometown - the Darjeeling hills. It is done either by nostalgically travelling down the memory lane or to compare it with the place of his visit. In "Mississauga Canada bata Isha Rotiwala ko Gospop Samjhinda" (Remembering Isha's Gospop from Mississauga) he meets his old school friend Suiba Lepcha in Canada. They spend hours talking about Kalimpong, about their school days and the Muslim baker from whom they used to steal Gospop (patties) at school. Through their conversation the readers get a hint about the life in Darjeeling hills, about responsibilities as eldest of siblings in the family, and hardships faced by students with limited resources. In the same narrative he also meets an engineer from Sikkim, Mr Upreti and his wife Rita. They sit and talk for hours on various issues related to Darjeeling, Kalimpong, Sikkim and Nepal. In another essay "Bardeli ma Baseyra Batuleyko Kosheli" (Gifts collected in a Balcony) he reaches Catania, Sicily. The flowers in the balcony of his room remind him of his native town Kalimpong along with Darjeeling and Sikkim. In "Hong Kong ko Hajam Bhanda Bhiyaa Hajam Kifiati"(The Hajam Bhaiya more economic to a barber in Hong Kong) he goes to a saloon at Baker's Street and pays what he thinks is sixty times more than what he pays to his barber, his hajam bhaiya back home. In "Sapna ko Sahar bhanda Sikhar ni Sundar" (The Peak is More Beautfiul than the City of Dreams) his friends take him to Timesun mountain in Hong Kong. There he meets a lot of Nepali people and is reminded of his village. He realizes that as a man from the mountains, he is more drawn towards nature than the city life. Here he compares Hong Kong's 'The Peak Tram' with Darjeeling's 'Toy Train'. During his travel in a Euro train in "Sicily Dekhi Jurich Samma ko Eurotrain Yatra" (Euro train journey from Sicily to Zurich) Solon thinks about National Highway 10 and National Highway 55 back home. He wonders whether the government and politicians are really serious about making Darjeeling hills 
into Switzerland. There are several essays where the journey itself is taken within and in the periphery of his native country and home town.

In his award winning book, essays like "1975 ko Delhi Diary" (Delhi Diary of 1975) and "Uut, Hati ra Bhandar ko Gulabi Sahar" (Camel, Elephant and Monkey's Pink City) narrate his travel experiences in Indian cities of Delhi, Jaipur and Kolkata. "Swacha Mausum ko Moj Padyatra ko Bhok ra Khoj" (Quest for a Clean Weather and a Trek) is an account of a trek he undertakes with seven teenaged children from his family to the far flung villages situated in the next hill from his home. He writes about his experiences with nature. On the trek they cross small rivers and hills. Throughout the journey he educates the accompanying children about local flora and fauna, at times reminiscing about his own childhood experiences when he and his friends used to walk those areas while going to play football in the neighboring villages. In this essay the reader gets a chance to know about the natural richness of the hills, about Lepcha people and their culture, about local culture, hospitality and the joys of simple rural life. The experiences are beautifully captured in his essay, forcing into the minds of readers a completely new perspective about local places. "Koirala Foolko Tarkari Khayenao" (We did not eat the Koirala Flowers) is yet another essay he where he captures local scenery, lifestyle, flora and fauna as he travels to Kurseong from Kalimpong. All along he is mesmerized and awestruck by the rich diversity of flora and fauna of the region. He feels elated. Whenever Solon writes about his native place in his essays, he feels elated and proud. He enjoys writing about the richness of the place from where he comes.

Similarly the characters whom he meets during his travels are sketched so vividly that they make a deep and everlasting impression in the reader's mind. They cannot be easily forgotten. Like the variety of places he writes about, so are his characters. They not only belong to different countries but also belong to different strata of society. The people whom he introduces to the readers could be an Italian engineer friend, a German couple- a family friend, a childhood friend who has got hold of a job in the police department at Canada, Dr. Karthak from Kalimpong who is doing good in Oakland, a Chinese landlord, a Nepali immigrant working as a taxi driver, guard, waiter or a cook in some foreign country, or a known person from his village settled away from his family to take care of mouths back home. Every time he meets someone he develops a strong bond with him. His deep conversation with the person slowly but steadily unfolds the character which helps him further to unearth the various aspects of the place and enlighten the reader at large. Whenever he comes to know about Nepali speaking people residing at different parts of the world, he becomes exited to meet them. He meets them and spends hours talking to them. These conversations are often Pandora's boxes that reveal so many things about the person and the places. The conversation is not always about the place where they are at present. When he meets his old friend Suiba Lepcha in Canada, they spend hours reminiscing about their childhood days and native place. At the same time the conversation and characters do not always give life at its best light. Coal mine workers Om Bahadur and San Kumar whom he meets at Arunachal, security guards Krishna Karki and Suraj Chettri whom he meets at Goa, restaurant waiter Krishna Bahadur Chettri whom he meets at Andaman, and Burmese Gorkha Dighkbir whom he meets at Bangkok, have their own woes and stories which shed light to the darker side of the society.

Solon's travelogues are a delight to readers. He does not confine himself to a particular space and time. The essays are not just boring travel guide books with mere information of facts and figures. Each essay is a creatively presented story and as the story flows, it unfolds and reveals many interesting things about the places, people and moments. He does not present only the beautiful side of his travels but on contrary, records the defects and vices of the places too. Be it, 
the places surrounding his home or land beyond seas, Solon has a power to present it in a unique style of his own. According to him, "to travel is a wonderful activity but to record it in writing is a wonderful opportunity." He records everything about the places he visits -- the scenic beauty, history, culture, lifestyle, food habits, people and experiences. Through these records Solon tries to introduce and inform his readers about the places he visits. He feels that the travel itself is not an end. A travel becomes meaningful for a traveller when he gains experiences and knowledge after the journey is made. He likes to present his native place along with its nature, his family, friends and society along with those of foreign shores, all the time educating his readers with something or the other. Many a time, we find Solon in a didactic mood giving his personal opinions, suggestions and advise.

Narbahadur Dahal, a noted figure in Nepali literature considers that a travel writer should be well versed with the historical, geographical, cultural, linguistic and socio-economic facts of the place about which he is writing along with a sound knowledge of the place from which the writer belongs to. He feels that a travel writer should never bring in wrong information about the place of which he is writing and similarly he should not give false information about his own place to fellow travellers. It is so because a reader of any travelogue would be travelling to different places through these writings. This is exactly what Solon Karthak does. Apart from this, his contribution to develop and bring Niyatra (Subjective Travelogue) into mainstream Nepali literature shall always be remembered. It is also very interesting to note that Karthak's writing is gradually being recognized in the academia. The story "Zebra Crossing ma Kukur ra Dolphin ko Namaskar" from his book Videsh Tira Ringdai Ghandaa (1991) is now taught in Class XII in the West Bengal Higher Secondary Board. Another essay "Swacha Mausum ko Moj Padyatra ko Bhok ra Khoj" (Quest for a Clean Weather and a Trek) from Padyatra Gaon ko Phanko Videshko (200o) has been recently shortlisted to be taught to the undergraduate students of the Nepali Department, North Bengal University. Finally, when this writer asked him what he thought were the reasons for getting recognition so very late in life, Karthak stated:

First and foremost I was not a smart enough to advertise my writings. We have very limited readership in mainland India. My works are not translated so I am an unknown person in the literary scenario of our country. In fact very little of our literature in known in the mainland. (Lepcha, 4 May, 2020)

\section{References}

Bandhu, Churamani. (2018). Nepali Lok Sahitya ko Itihas (Prathm Khanda).Kathmandu: Ekta Publications.

Karthak, S. (1986). Samudra wari Samudra pari. Darjeeling: Jiwan Jyoti Prakashan.

---. (1991). Videsh Tira Ringdai Ghandaa. Kalimpong: Sarikar Publication.

---. (200o). Padyatra Gaon ko Phanko Videshko. Kalimpong: Sarikar Publication.

---. (2013).Visva Eauta Pallo Gaon. Kalimpong: Sarikar Publication.

---. (2018). Golard Ghumai ka Raang Haru. Kalimpong: Upama Publication.

Lepcha, N. M. A personal interview with Solon Karthak. Unpublished. May 4, 2020.

Pradhan, Kumar. (1984). A History of Nepali Literature. New Delhi: Sahitya Akademi.

The Sikkim Express. (25 January 2020). Sahitya Akademi Award for Litterateur Salon Karthak. http://www.sikkimexpress.com/news-details/sahitya-akademi-award-for-litterateur-salon-karthak 